\title{
硬化型復元力特性を有する部材により耐震補強した多層骨組の振動特性 DYNAMIC CHARACTERISTICS OF MULTI-STORY FRAMES RETROFITTED BY A DEVICE WITH HARDENING TYPE HYSTERESIS
}

\author{
渡辺宏一*, 中井正一** \\ Koichi WATANABE and Shoichi NAKAI
}

\begin{abstract}
When making repairs to buildings affected by earthquakes, restoration by just adding strength is commonly used. However, this causes a large change in the axial force on the piles because of the increase in the overturning moment. In this paper, when applying seismic retrofit by using a device with hardening type hysteresis, it was revealed that the increase in overturning moment could be controlled and the maximum ductility factor could be reduced. Furthermore, we proposed a prediction formula for the maximum ductility factor when there is a weak story in the building.
\end{abstract}

Keywords : Hardning type hysteresis, Maximum ductility factor, Overturning moment, weak story, MDOF shear-tyrp model 硬化型復元力特性，最大塑性率，転倒モーメント，弱層，多自由度せん断型モデル

\section{1. はじめに}

1981 年に新而震設計法が施行された。それ以降に建設された構造 物については大地震時にも層崩壊などの修復不可能なレベルの被害 を受けることは少ないと予想される。しかし、構造部材になんらか の損傷を受けることは十分に考えられ、被災後の補修を適切に行う ことが必要となる。残留耐力評価 1) や補修後耐震性能に関する実験 的研究 2) も行われているが、残存耐力や補修後耐力を精度よく推定 することは現実的には難しい。

被災建物の残存耐力が不明の場合には、安全性の観点から過剩に 耐震補強する必要がでてくる。その結果、建物の短周期化により転 倒モーメントが増大し、建物下層部の柱や杭の軸力変動も大きくな る。過去の震災では、液状化や側方流動等の痕跡が無いにも関わら ず地震時の高軸力により杭頭部が破壊されて上部建物が傾斜した被 害例 3) がある。また、杭軸力が大きいほど先行して杭が破壊すると した載荷試験結果 4) も報告されている。既存建物の杭の補強は極め て困難なため、転倒モーメント増加を抑制できる耐震補強法が必要 とされる。また、最適な降伏せん断力係数分布となるように建物諸 元を設定することは多層骨組の損傷低減に有効であるが、残存耐力 を精度よく評価できなければ、補修後の建物に弱層が存在すること は避けられない。この場合には補修後に発生寸る地震により、弱層 一損傷が集中して層崩壊につながる恐れもある。そのため、任意の 層に弱層がある場合の損傷集中度の定量的な評価手法が必要である。

著者ら 5),6),7) は、弱層が存在寸る場合にも損傷分散効果により層 崩壊を抑制できる耐震補強法として、層間変形がギャップ量を超え
た場合に補強部材が作動するような硬化型復元力特性を用いた補強 方法（以後、硬化型補強と呼ぶ）を提案している。硬化型復元力特 性については、既に 1950 年代に小堀等が twisted wire を用いた硬 化型復元力システムを提案し、解析的検討により新しい耐震構造形 式の可能性を示唆した ${ }^{8)}$ 。井上等はエネルギー応答に基づいて応答 塑性率を目標值以下に収めるために必要なダンパー量とリミッター の適切なギャップ量を算定する手法を提案している ${ }^{9)}$ 。秋山らはエ ネルギーの釣り合いに基づき、弱層がある場合の損傷分布を損傷集 中係数 $n$ により評価している ${ }^{10)}$ 。多層建物の応答予測に関寸る研究 としては、小堀等による高層構造物の適正動力学特性に関する一連 の研究がある 11),12),13)。剛性分布や減衰の影響、塑性率の高さ方向分 布等についても言及されており、本論文で得られた知見とも整合し ている。縮約等価 1 自由度系によって多層建築物の地震応答を推定 する試みも精力的に行われている。例えば、倉本らは高次モードを 考慮できる評価方法を提案している ${ }^{14)}$ 。笠井らは粘弾性ダンパーを 用いた制御構造の応答制御設計法を提案している ${ }^{15)}$

本論文では、多層建物を対象とした硬化型補強の応答低減メカニ ズムを解明し、従来型補強と比較した場合の有用性を明らかにする。 評価指標は、転倒モーメントと最大塑性率である。骨格曲線の形状 に着目し、硬化型補強の応答低減メカニズムや弱層がある場合の塑 性率の増加量を、減衰項を考慮した疑似的な力の釣り合いから説明 できることを示す。なお、計算機の性能向上により多層せん断棒の 時刻歴応答解析が短時間で可能となってきていることから、本論文 では、得られた知見を実用的な観点から整理し、少数の応答計算結
$*$ 清水建設技術研究所 工修

** 千葉大学大学院工学研究科 教授. 工博
Institute of Technology, SHIMIZU Corporation, M. Eng. Prof., Graduate School of Engineering, Chiba Univ., Dr. Eng. 
果を用いて評価指標を簡易的に算定する手順も示す。

2 章では対象とする解析モデルについて述べる。3 章では弱層が ない場合の応答解析結果について考察し、減衰項を考慮した層せん 断力と塑性率の関係式 7) を多層に拡張する。4 章では弱層の有無に よる応答解析結果について考察し、弱層が無い場合の塑性率から弱 層がある場合の塑性率予測式を提案寸る。 5 章では、弱層がある場 合の最大塑性率や転倒モーメントの予測手順を示す。

\section{2. 解析モデル}

図 1 に示すような 10 層せん断モデルを作成した。既存建物の $i$ 層 のば称剛性 $k_{i}$ は、最下層剛性 $k_{1}$ と最上層剛性 $k_{N}$ を補間して求めた。 $k_{1} / k_{N}$ は図中に示した值とした。既存建物の固有值解析を行い、 1 次固有值 $T$ が解析条件值になるように $k_{1}$ を設定した。既存建物はバ イリニア復元力でモデル化し、2 次勾配はゼロとした。1 層の降伏 せん断力を $F_{y 1}$ としたときの高さ方向の分布は $A i$ 分布により設定 した。 $i$ 層の減衰は $c_{i}=h k_{i} T / \pi$ で設定した。

図 2 に各補強法による復元力特性を、図 3 に骨格曲線の比較を示 す。 $F$ は層せん断力、 $f$ は層せん断力係数である。添え字の $y 、 m 、$ aはそれぞれ降伏点、既存建物、補強部材を示す。なお、ここでは $i$ 層を示寸下添え字 $i$ は省略している。塑性率 $\mu$ は各層の応答層間 変位 $u$ を降伏変位 $u_{y}$ で除した值 $\left(\mu=u / u_{y}\right)$ である。従来型補強 の復元力は、補強倍率 $p$ の初期剛性を持つ線形としてモデル化する。 ここで、補強倍率 $p$ は従来型補強の初期剛性を既存建物の初期剛性 で除した值である。

硬化型補強の復元力は、 $\mu \leq g$ ではせん断力を負担せず、 $\mu \geq g$ で は傾き $p_{g}$ を持つ非線形弾性としてモデル化する。ここで、ギャッ プ率 $g$ はギャップ変位 $u_{g}$ を降伏変位 $u_{y}$ で除した值 $\left(g=u_{g} / u_{y}\right)$ である。各補強法による応答低減効果の評価は、主に $1 \leq \mu \leq 3$ の範 囲で行うこととした。そこで、 $\mu \geq g$ での傾き $p_{g}$ は、塑性率 $\mu=2$ に おいて硬化型補強と従来型補強の層せん断力が交差するように $p_{g}=2 p /(2-g)$ で設定した。ギャップ率 $g$ に関する予備解析（付録 参照）を行った結果、 $g=1$ 近傍において硬化型補強の応答低減効果 が大きかったことから、本論文では $g=1$ に限定して検討する。硬化 型補強においても、骨格曲線を合成した補強建物全体では硬化域は 存在しないため、本検討では衝突現象は発生しない。なお、硬化型 補強を具現化する装置や、建物内に配置した場合の局所的な衝突現 象の検討は今後の課題する。

復元力特性の骨格曲線の剛性を比べると、(a)従来型補強建物では $\mu \leq 1$ で $1+p 、 \mu \geq 1$ で $p$ であるのに対し、(b)硬化型補強建物では、 $\mu \leq 1$ で $1 、 \mu \geq 1$ で $g=1$ の場合は $2 p$ となる。また、おなじ塑性率 では履歴吸収エネルギー（図 2 の薄塗部の面積）が一致する。

図 4 に示寸ように、被災して残存耐力が低下した既存建物に対し て、被災前の耐力レベルまで補修された場合と、不十分な補修によ り弱層が発生する場合を考える。弱層は既存建物の 1 つの層で発生 し、弱層以外の層は被災前の耐力レベルまで補修されているとする。 弱層は、初期剛性および降伏せん断力に弱層倍率 $\varphi=0.8$ を乗じるこ とで表現しているため、降伏点の塑性率は弱層でない場合と同じに なる。このような弱層を含有する補修後の既存建物に対して、さら に従来型補強と硬化型補強を施した場合の耐震性能を比較寸る。

入力波としては、スペクトル特性の影響を極力抑えた傾向を見る
ために、ランダム位相の告示スペクトル 100 波を用いた。図 5 に速 度応答スペクトルの平均值， $\pm \sigma, \pm 2 \sigma$ と加速度波形の例を示す。応 答解析結果についても 100 波の平均值を用いた。波形倍率 $\gamma$ は、 $\gamma=1 / \mu_{\text {mean }}$ で定義した。ここで、 $\mu_{\text {mean }}$ は次の手順で算定した。ま ず、弱層なしの線形モデルについて線形時刻歴解析を行い各層の層 間変形 $u_{e l}$ を求める。非線形モデルの各層の降伏変位 $u_{y}$ で $u_{e l}$ を除 した值について全層での最大值を求める。 $\mu_{\text {mean }}$ は、入力 100 波に 対して求めた最大值の平均值とする。入力波によりばらつきはある ものの、波形倍率 $\gamma=1$ のときが弱層なしモデルが降伏する目安とな っている。表 1 に解析条件一覧を示す。非線形時刻歴解析の継続時 間は 80 秒、時間刻みは 0.01 秒とした。

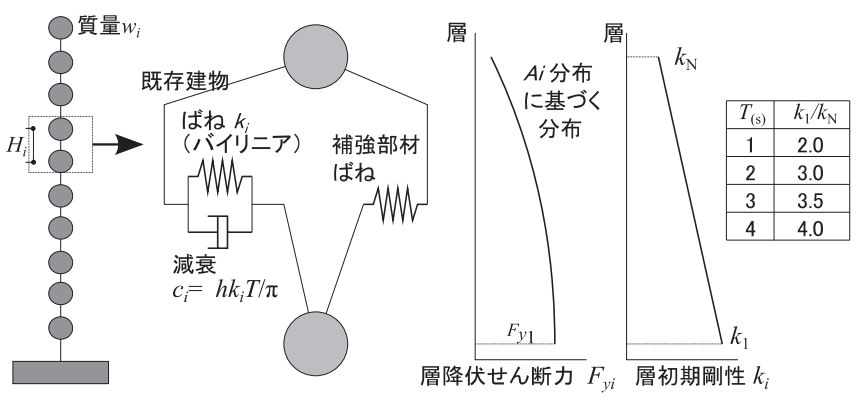

図 1 解析モデル

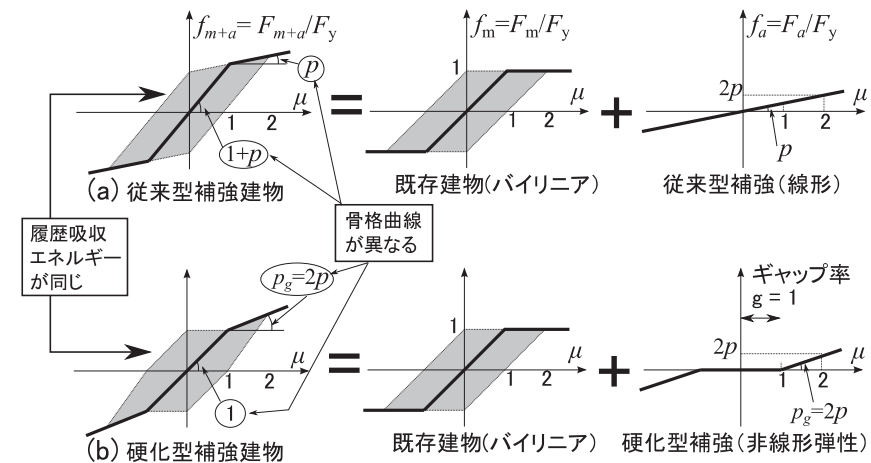

図 2 復元力特性 (硬化型補強は $g=1$ の場合)

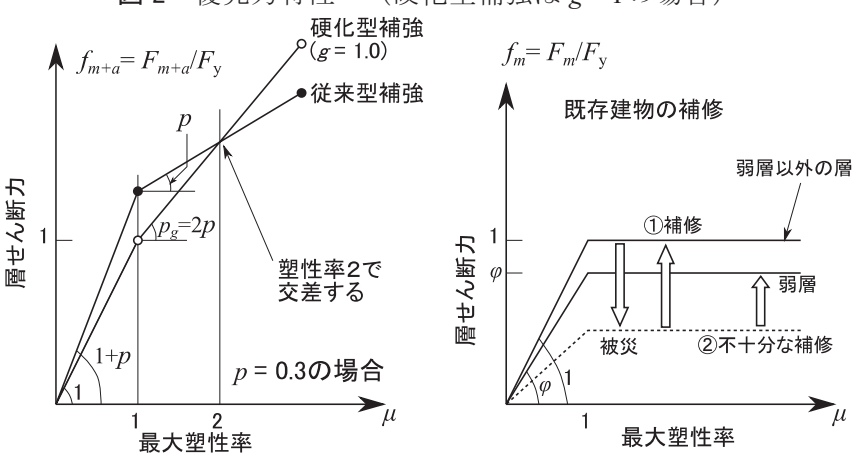

図 3 骨格曲線の比較図 4 既存建物の補修と弱層

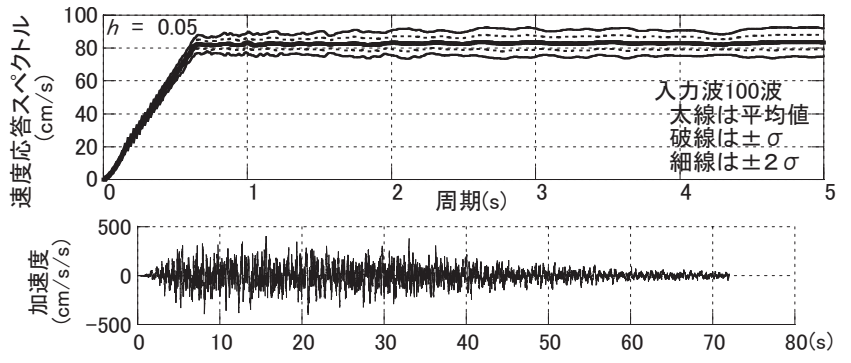

図 5 速度応答スペクトルと加速度波形の例 
表 1 解析条件

\begin{tabular}{|c|c|c|c|c|}
\hline \multirow{2}{*}{ 項目 } & \multicolumn{2}{|c|}{3.4 節以外の検討用 } & \multicolumn{2}{|c|}{3.4 節の検討用 } \\
\cline { 2 - 5 } & 範囲 & パラメタ数 & 範囲 & パラメタ数 \\
\hline $\begin{array}{c}\text { 既存建物の } \\
\text { 固有周期 } T(\mathrm{sec})\end{array}$ & $1,2,3,4$ 秒 & 4 & 同左 & 4 \\
\hline 層数 $N$ & 10 & 1 & $1,5,10,40$ & 4 \\
\hline 弱層位置 & $\begin{array}{c}\text { 弱層なし、, } \\
\text { 弱層あり } 1 \mathrm{~F}, 5 \mathrm{~F}, 9 \mathrm{~F})\end{array}$ & 4 & 弱層なし & 1 \\
\hline 減哀定数 $h$ & $0.02,0.05,0.10$ & 3 & 同左 & 3 \\
\hline 補強種別 & $\begin{array}{c}\text { 従来型補強 }(g=0.0) \\
\text { 硬化型補強 }(g=1.0)\end{array}$ & 2 & 同左 & 2 \\
\hline 補強倍率 $p$ & $0.0,0.1,0.2,0.3$ & 4 & $0.0,0.1,0.3$ & 3 \\
\hline 波形倍率 $\gamma$ & $0.2,0.8,1.0 \sim 3.0(0.2$ 刻み $)$ & 13 & 同左 & 13 \\
\hline 波形数 & 100 波 & 100 & 同左 & 100 \\
\hline 計算ケ一ス総数 & & 499200 & & 374400 \\
\hline
\end{tabular}

\section{3. 解析結果の考察（弱層がない場合）}

\section{1 塑性率と転倒モーメントの関係}

図 6 に弱層がない場合の塑性率と転倒モーメントの関係を示す。 $m=M / M_{e}$ は転倒モーメントの無次元量である。 $M$ は転倒モーメ ント、 $M_{e}$ は全層降伏時の転倒モーメントで(1)式による。

$$
M_{e}=\sum_{i=1, N} F_{y i} H_{i}
$$

図中の上段は波形倍率が増える方向に線分で結んだものであり、 図 3 の骨格曲線に類似した傾向となっている。このことから、初期 剛性が小さいほど転倒モーメントを小さくできることがわかる。な お、両補強法の転倒モーメントが同レベルになるのは塑性率が 2 を 大きく超える領域となっている。これは、全層の塑性率が同一でな いことや発生時間のずれが影響しているためである。図中の下段は 波形倍率 $\gamma=1.0,1.6,2.2$ について補強倍率を増やした場合の従来型 補強と硬化型補強の応答の違いを示している。従来型補強と比較し て、硬化型補強では転倒モーメントの増加が抑制されている。
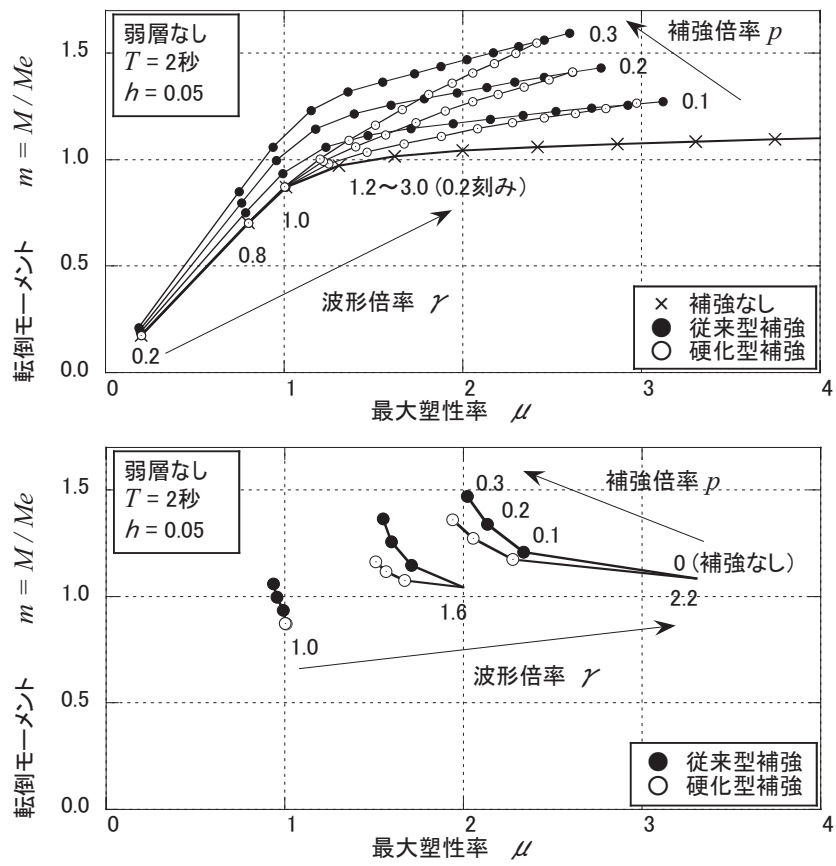

図 6 転倒モーメント

\section{2 塑性率と最大応答加速度の関係}

図 7 に塑性率と最大応答加速度の関係を示寸。検討対象の硬化型 補強では既存建物の剛性低下の一部を補っているだけであるので、 衝突時に発生するような大きな加速度は発生しない。図 6 と同じ傾 向を示しており、従来型補強と比較しても最大加速度は小さい。

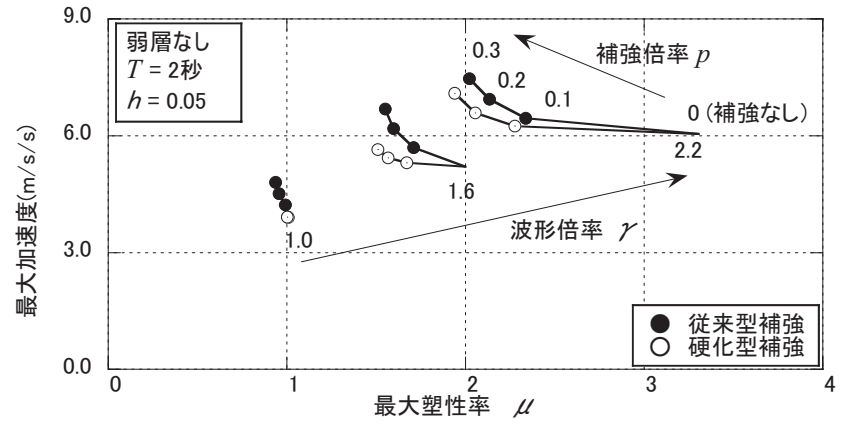

図 7 塑性率と最大応答加速度の関係

\section{3 塑性率の高さ方向の分布}

図 8 に塑性率の高さ方向分布を示す。 $A i$ 分布に基づいて作成し たモデルであり、塑性率 $\mu=1$ 近傍では高さ方向のばらつきは少ない。 また、減衰が大きい場合は下層部で塑性率が大きくなる傾向がある。 このことは小堀ら 12）も指摘しており、笠井ら 16) も減衰の影響を考 慮した修正 $A i$ 分布を提案している。塑性率 $\mu \geq 1$ では、弾性域で相 対的に塑性率が大きかった層において塑性率が大きくなる傾向があ る。弾性限強度分布が塑性率分布に大きく寄与するという小堀ら ${ }^{13)}$ の指摘とも整合している。また、層塑性率については、硬化型補強 の方が平準化効果が大きい。
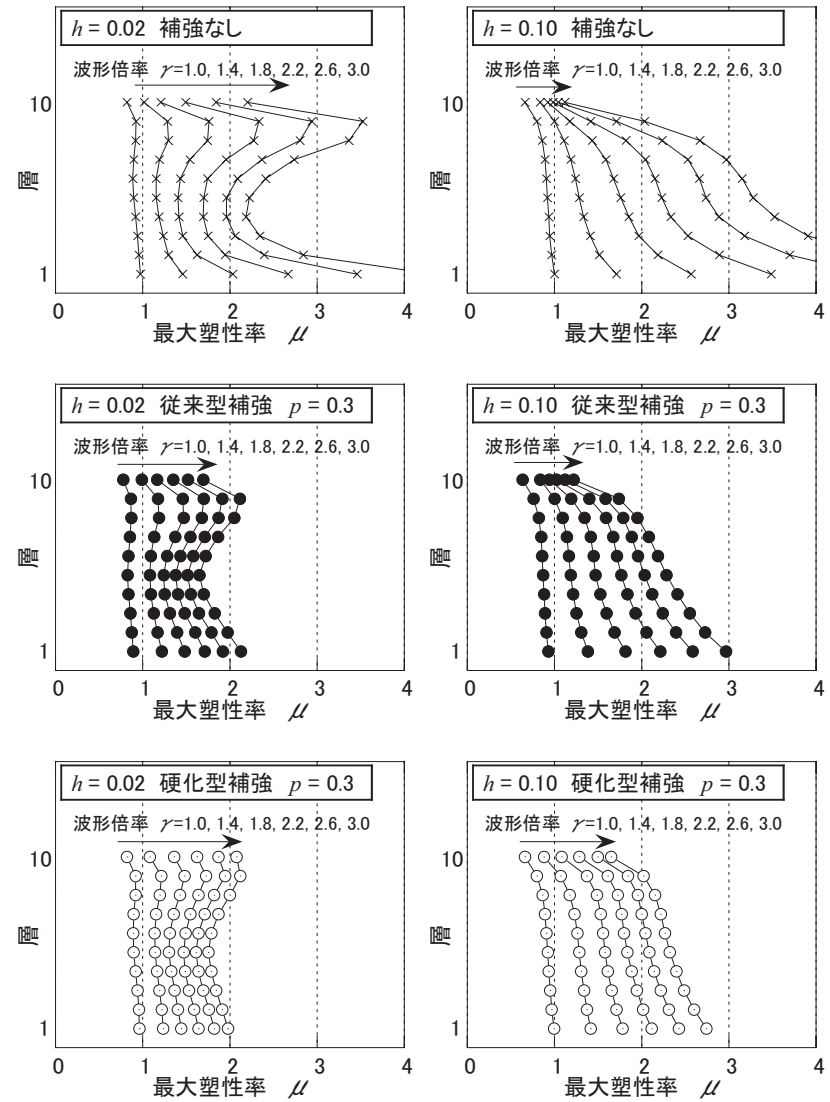

図 8 塑性率の高さ方向分布（弱層なし、 $T=2$ 秒） 
図 9 に、固有周期 $T=2$ 秒、減衰定数 $h=0.05$ 、硬化型補強 $p=0.3$ の場合の波形倍率と各層の塑性率の関係を示す。縦軸は、塑性率 $\mu$ を波形倍率 $\gamma=1$ のときの塑性率 $\mu_{\gamma=1}$ で基準化した值 $\eta=\mu / \mu_{\gamma=1}$ で ある。波形倍率 $\gamma$ の増加に伴い、各層の $\eta$ は滑らかに増加している ことから、 $\gamma$ との関係を次式で近似する。

$$
\begin{array}{ll}
\gamma \leq 1 \text { のとき、 } & \eta=\gamma \\
1 \leq \gamma \text { のとき、 } & \eta=\gamma^{n}
\end{array}
$$

$(2 \mathrm{~b})$ 式の $n$ は $1 \leq \gamma$ における各層の塑性率の増大傾向を表す係数 である。ここで、例えば $\gamma=3$ のときの各層の $\eta$ を用いると、各層每 に $n$ を定めることができる。なお、図 8 から、塑性率の増大傾向は 減衰定数や補強方法により差があるため、 $n$ はそれらの解析条件ご とに求める必要がある。図 10 に、(2)式による各層の塑性率の予測 結果と応答解析結果の比較を示す。図より、波形倍率 $0 \leq \gamma \leq 3$ に対 する各層の塑性率が、波形倍率 $\gamma=1$ と $\gamma=3$ の応答解析結果から精 度良く予測できることが分かる。

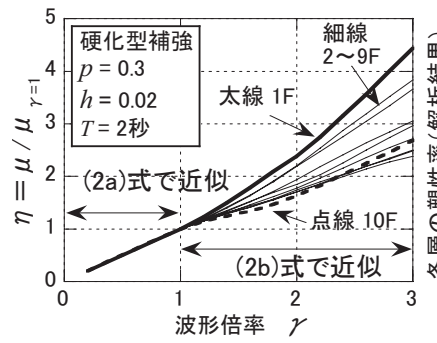

図 9 波形倍率と各層塑性率

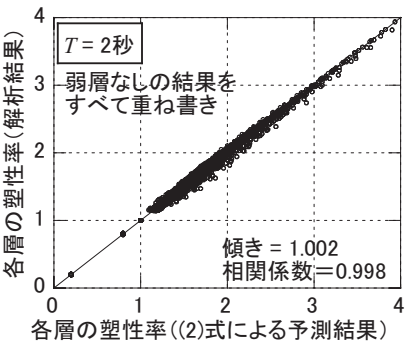

図 10 各層塑性率の予測結果

\section{4 減衰項を考慮した層せん断カと最大塑性率の関係}

減衰項を考慮した最大せん断力については笠井らにより強制正弦 変形を仮定した詳細な算出式が既に提案されている ${ }^{17)}$ 。著者等も 1 層モデルを対象とした応答解析結果より、入力波の高振動数成分に よる割増も考慮した簡易式を提案している7)。ここで、1,5,10,40 層モデルの時刻歴応答解析を行い、1 層モデルの簡易式が多層モデ ルの各層においても成り立つことを確認した((3)式)。なお、以下で は、骨格曲線の初期剛性と 2 次勾配をそれぞれ $p_{1}, p_{2}$ と置くことに より、従来型補強と硬化型補強を統一した式で表している。 $\alpha_{1}, \alpha_{2}$ は 骨格曲線と減衰項に関する係数で、 $\beta_{1}, \beta_{2}$ は高次振動数成分による 割増係数である。図 12 に、固有周期 2 秒、減衰 $h=0.10$ の場合の層 せん断力の予測結果を示す。補強倍率が小さいほど減衰項の影響が 大きいことがわかる。図 13 に予測精度の高さ方向分布を示す。図 中上段は高さ方向の補正をしていない $\beta_{1}, \beta_{2}$ を用いた場合で、下段 は高さ方向の補正をした $\beta_{1}{ }^{\prime}, \beta_{2}{ }^{\prime}$ を用いた場合である。補正前では、 下層および上層で小さめに、中間層で大きめに層せん断力が評価さ れている。また、この傾向は層数には依存しない。これは、下層は 入力地震波の高振動数成分が、上層では建物固有振動数の高次成分 が影響しているためと考えられる。

$$
\begin{aligned}
f_{\max }=f_{m 2}+f_{a 2}+f_{e} & \\
\text { ここで、 } \mu \leq 1 \text { の場合、 } & f_{e}=a_{1} \beta_{1} \mu \\
& \mu \geq 1 \text { の場合、 } \quad f_{e}=a_{1} \beta_{1} \mu+\alpha_{2} \beta_{2} \sqrt{\mu-1}
\end{aligned}
$$

$$
\begin{array}{ll}
\alpha_{1}=\sqrt{p_{1}^{2}+4 h^{2}}-p_{1} 、 、 & \alpha_{2}=\sqrt{p_{2}^{2}+4 h^{2}}-p_{2} \\
\beta_{1}=1+0.3 t_{0} & \beta_{2}=\left(1+0.3 t_{0}\right)\left(0.66+4 p_{2}\right)
\end{array}
$$

従来型補強の場合、 $p_{1}=1+p 、 p_{2}=p$

硬化型補強の場合、 $p_{1}=1 、 p_{2}=2 p$

高さ方向の補正をする場合

$$
\begin{aligned}
& \beta_{1}^{\prime}=\left(1+0.3 t_{0}\right)(0.9+2 c+1.5 d) \\
& \beta_{2}^{\prime}=\left(1+0.3 t_{0}\right)(0.5+0.4 c+1.4 d)\left(1+2 p_{2}\right)
\end{aligned}
$$

ここで、 $i$ は層番号、 $N$ は層数、 $c=\left(1-x_{i}\right)^{4} 、 d=x_{i}^{4} 、 x_{i}=(i-0.5) / N$

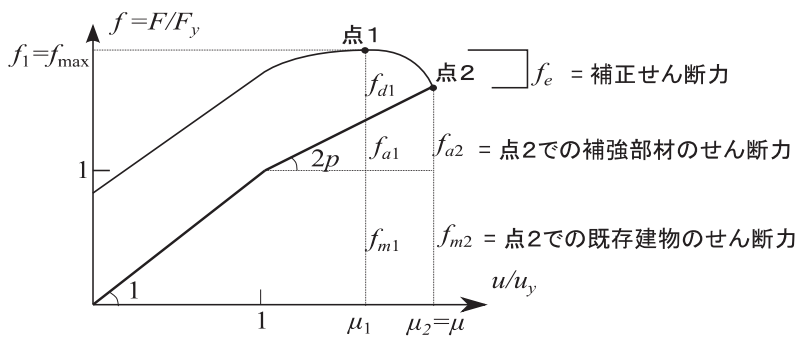

図 11 硬化型補強時の層せん断力の内訳
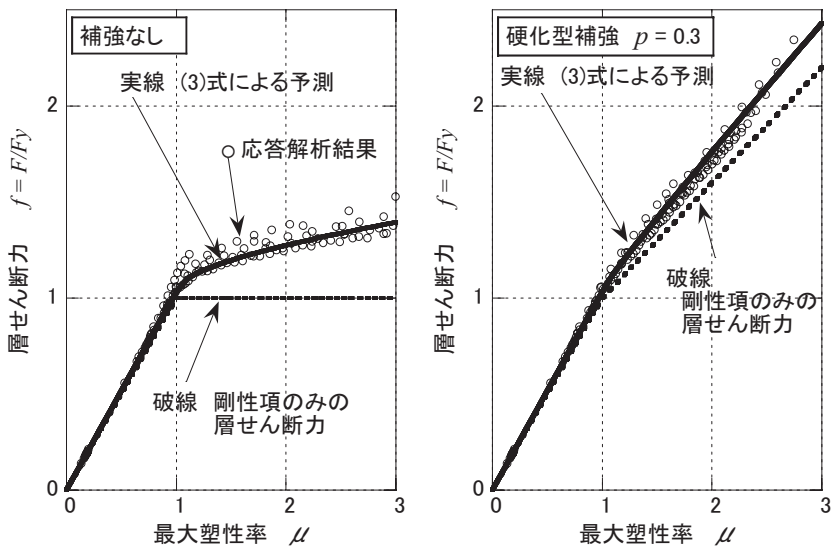

図 12 層せん断力の予測

（弱層なし、 $T=2$ 秒、 $h=0.10 ）$
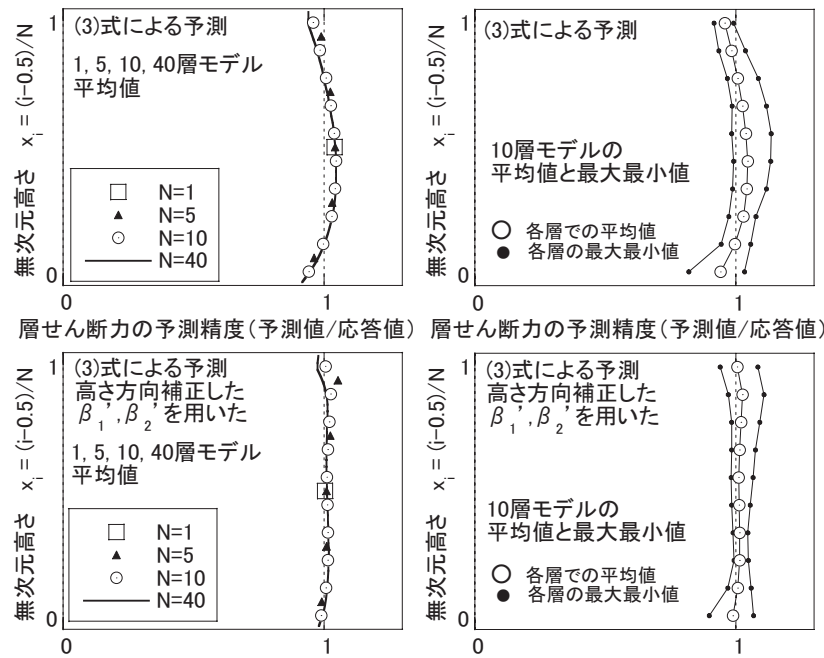

層せん断力の予測精度 (予測值/応答値) 層せん断力の予測精度 (予測值/応答值) 図 13 層せん断力の予測精度の高さ方向分布 


\section{5 層せん断カによる転倒モーメントの予測}

層せん断力を用いた(4)式により転倒モーメントを予測し、応答解 析結果と比較した。ここで、 $m^{\prime}$ は転倒モーメント予測值とし、全 層降伏時のせん断力を用いて算定できる静的転倒モーメント $M_{e}$ で 無次元化してる。

$$
m^{\prime}=\sum_{i=1, N} F_{i} H_{i} / M_{e}
$$

図 14 に、固有周期 $T=2$ 秒の場合の転倒モーメントの予測結果を 示す。予測值と応答解析結果はほぼ線形関係にあり (5)式で回帰する と補正係数 $\lambda$ は 0.936 となった。表 2 に、各固有周期毎の補正係 数 $\lambda$ を示す。高次モード成分の影響により固有周期が大きいほど $\lambda$ は小さくなっている。

$$
m=\lambda m^{\prime}
$$

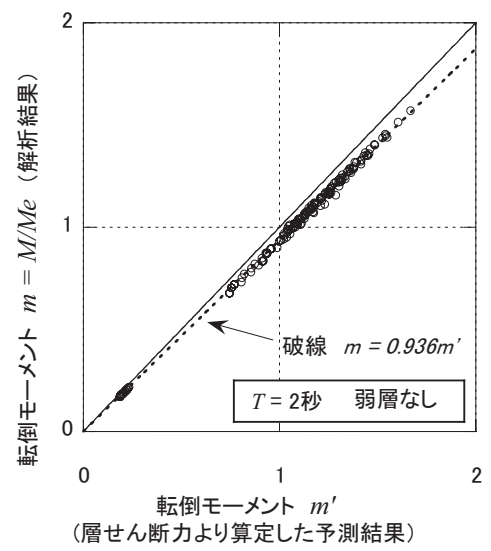

表2
\begin{tabular}{|c|c|c|}
\hline $\begin{array}{c}\text { 各周期毎の補正係数 } \\
\text { 周期 } \\
T\end{array} \begin{array}{c}\text { 補正係数 } \\
\lambda \\
=m / m^{\prime}\end{array}$ & 相関係数 \\
\hline 1 & 0.975 & 1.000 \\
\hline 2 & 0.936 & 0.999 \\
\hline 3 & 0.921 & 0.999 \\
\hline 4 & 0.914 & 0.999 \\
\hline
\end{tabular}

図 14 層せん断力から算定した転倒モーメント

\section{4. 解析結果の考察（弱層がある場合）}

\section{1 塑性率と転倒モーメントの関係}

図 15 に弱層の有無による塑性率と転倒モーメントの関係を示す。 図より、転倒モーメントは弱層の有無にあまり影響されないこと、 また、最大塑性率は弱層がある場合に大きくなるが、硬化型補強で は塑性率の増大が抑制されていることがわかる。図 16 に従来型補 強に対する硬化型補強の応答低減量を示す。横軸は従来型補強時の 最大塑性率である。最大塑性率については、 $\mu=1.5$ 付近までは硬化 型補強が大きくなるが、それ以降は低減効果がみられる。転倒モー メントについては、 $\mu=3.0$ 付近までは硬化型補強が小さくなること、 補倍率 $p$ が大きいほど低減量が大きくなることがわかる。

以上のことから、従来型補強で塑性率 $\mu=1.5 \sim 3.0$ の応答が想定 される場合には、硬化型補強にすることによって、最大塑性率と転 倒モーメントの両方を低減できる。転倒モーメントの低減は下層部 隅柱や杭の軸力変動の低減にも直結する。アスペクト比が大きな $\mathrm{RC}$ 造建物などでは、 $M-N$ 降伏曲面において曲げ降伏耐力が急激に 低下寸るレベルに軸力がある状況も考えられることや、柱の変形能 力が圧縮軸力の増大に伴って低減すること 18) を考慮すると、転倒モ ーメントの 1〜2 割の低減は耐震性能の向上に有意義である。
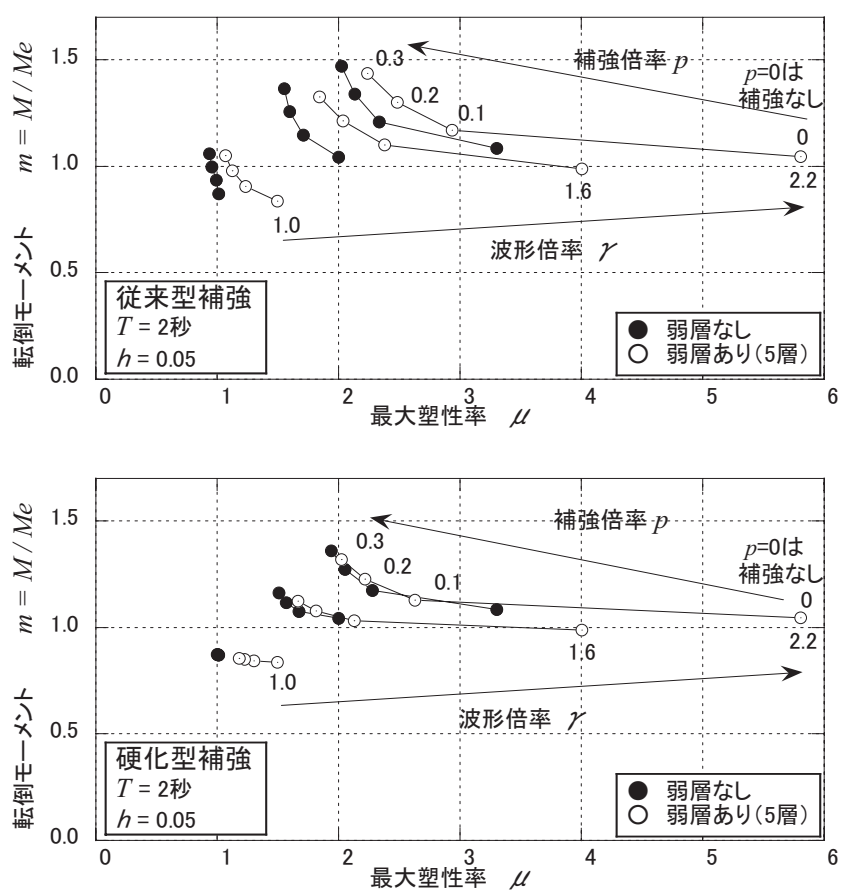

図 15 塑性率と転倒モーメントの関係（弱層の影響）
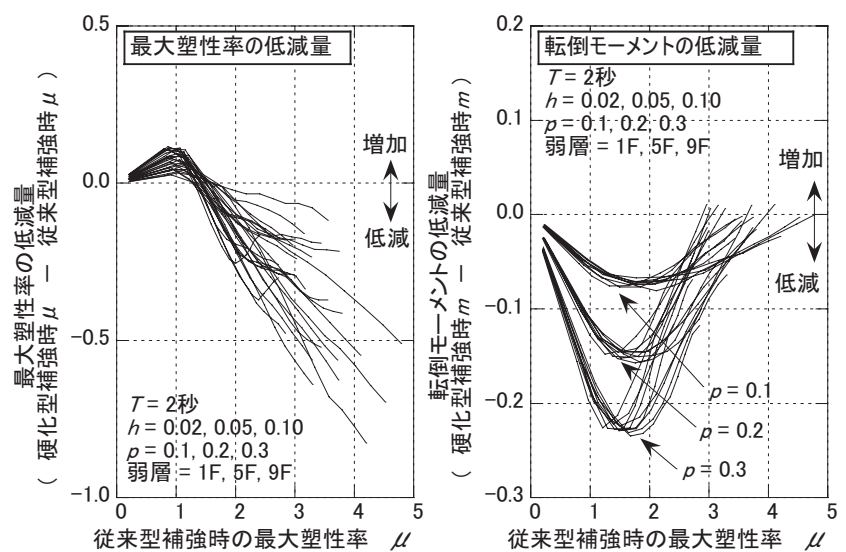

図 16 硬化型補強時の応答低減量

\section{2 弱層の有無による転倒モーメントの変化}

図 17 に弱層が無い場合の転倒モーメントと弱層がある場合の転 倒モーメントの関係を示す。図中には、す心゙ての解析ケースを含ん でいる。図より、弱層の有無は転倒モーメントにはほとんど影響な いことがわかる。

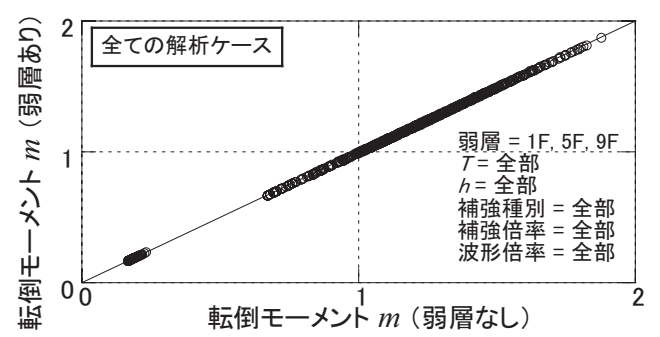

図 17 弱層の有無による転倒モーメントの変化 


\section{3 弱層の有無による最大塑性率と層せん断力の変化}

図 18 に弱層の有無による層塑性率と層せん断力の変化を示寸。 ここで、層せん断力には減衰項も加算されている。弱層があっても 層せん断力の高さ方向分布は比較的滑らかに連続している。剛性分 布が変動しても層せん断力に殆じ影響しないことは小堀ら 11) も指 摘している。補強倍率が小さい場合、弱層の層せん断力は弱層が無 い場合の当該層の層せん断よりも小さくなる。特に、層塑性率 $\mu=1$ 周辺ではその傾向が顕著である。一方、補強倍率が大きい場合、弱 層の有無によるせん断力の変化は極めて少ない。図 19 は、補強倍 率の違いによるせん断力低減量の変化についての説明図である。こ の図の層せん断力には減衰項を含んでいない。補強倍率が小さい場 合、高さ方向の層せん断力が滑らかになるために、弱層の塑性率が 急増し、反対に周辺層の塑性率は小さくなる。特に周辺層の塑性率 が $\mu=1$ の近傍の場合にはその傾向が顕著である。一方、補強倍率が 大きい場合には、弱層の塑性率がわずかに増えるだけで、周辺層と の層せん断力の連続性が満足されるため、弱層のせん断力がほとん ど低下しない。
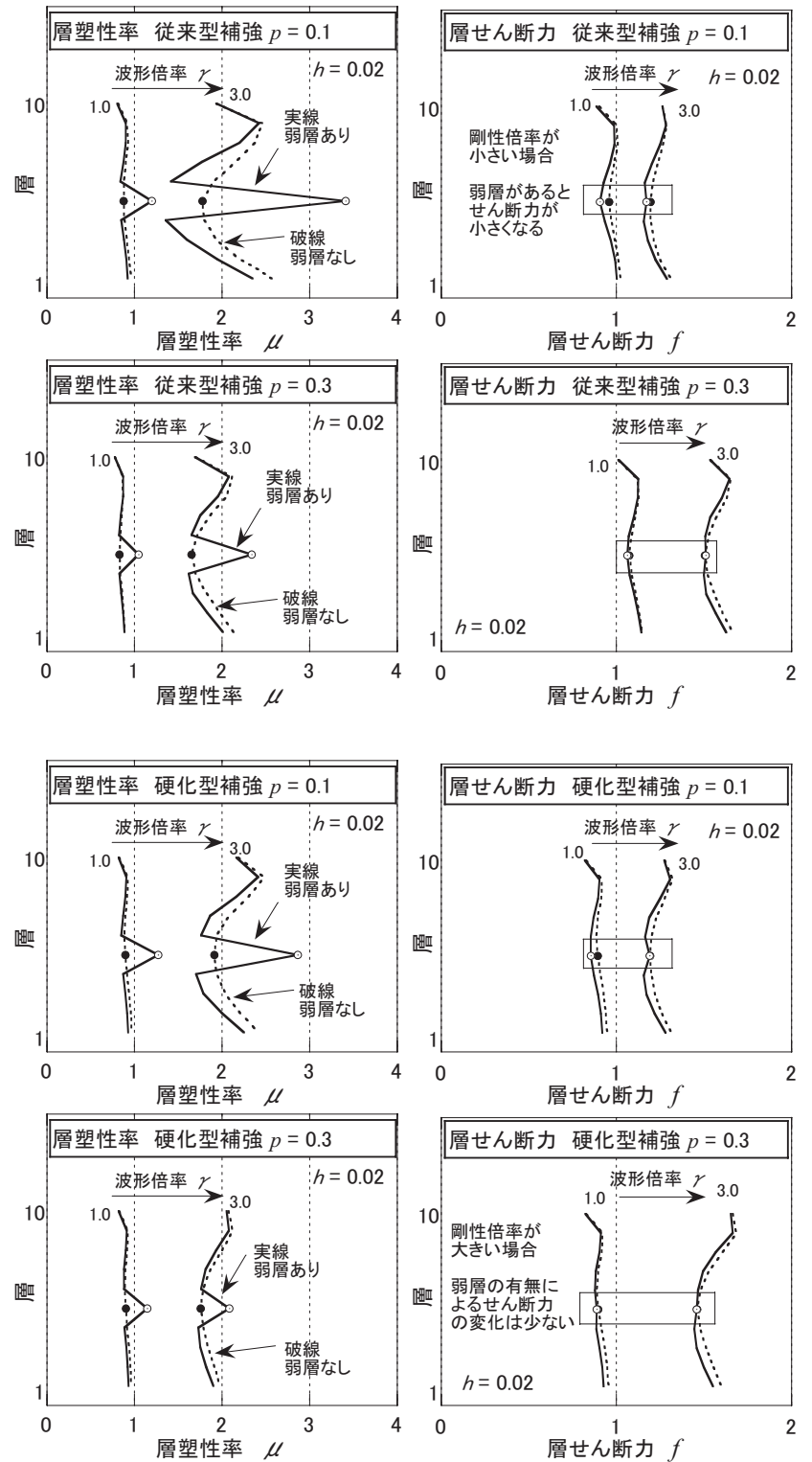

図 18 弱層の有無による塑性率とせん断力の変化

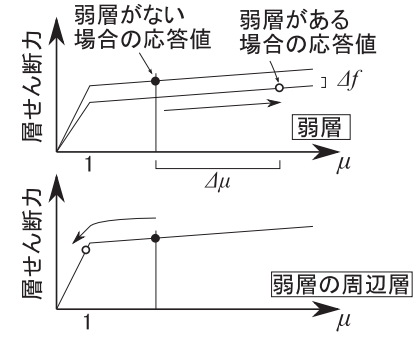

補強材の剛性 $p$ 小さい場合

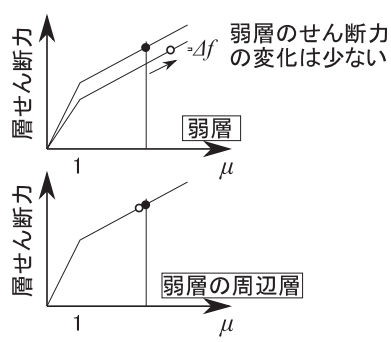

補強材の剛性 $p$ が大きい場合
図 19 補強倍率の違いによるせん断力低減量の変化

\section{4 弱層がある場合の塑性率の予測}

弱層が無い場合の塑性率と層せん断力を $\mu, f(\mu)$ 、弱層がある場 合の塑性率と層せん断力を $\mu^{\prime}, f^{\prime}\left(\mu^{\prime}\right)$ とする。ここで、補強倍率が 大きい場合には次式が成り立つと仮定する。

$$
f(\mu)=f^{\prime}\left(\mu^{\prime}\right)
$$

塑性率と層せん断力の関係式 ((3)式) を(6)式に代入すると弱層が 無い場合の塑性率 $\mu$ から弱層がある場合の塑性率 $\mu^{\prime}$ の予測式が導 ける。

$$
\begin{aligned}
& \mu \leq \mu_{c} \text { のとき } 、 \mu^{\prime}=\mu / \mu_{c} \\
& \mu_{c} \leq \mu \text { のとき、 } \mu^{\prime}=\left(1-2 a b-\sqrt{1-4 a b-4 b^{2}}\right) /\left(2 b^{2}\right)
\end{aligned}
$$
ここで、

$$
\begin{aligned}
& \mu_{c}=\left(\varphi+p_{1}-1+\alpha_{1} \beta_{1}\right) /\left(p_{1}+\alpha_{1} \beta_{1}\right) \\
& a=\left(\varphi+p_{1}-p_{2}-1-f(\mu)\right) / \alpha_{2} \beta_{2} \\
& b=\left(\alpha_{1} \beta_{1}+p_{2}\right) / \alpha_{2} \beta_{2}
\end{aligned}
$$$$
f(\mu)=p_{1} \mu+\alpha_{1} \beta_{1} \mu
$$

$f(\mu)=p_{1}+p_{2}(\mu-1)+\alpha_{1} \beta_{1} \mu+\alpha_{2} \beta_{2} \sqrt{\mu-1}$

なお、 $\alpha_{1}, \alpha_{2}, \beta_{1}, \beta_{2}, p_{1}, p_{2}$ は(3)式中の定義による。

補強倍率 $p$ が大きい場合には、相対的に減衰項の影響は小さくな る。ここで、減衰 $h=0$ とすると次式のようになる。

$$
\begin{array}{ll}
\mu_{c}=\left(\varphi+p_{1}-1\right) / p_{1} & \\
\mu \leq \mu_{c} \text { のとき、 } & \mu^{\prime}=\mu / \mu_{c} \\
\mu_{c} \leq \mu \leq 1 \text { のとき、 } & \left.\mu^{\prime}=\left(1-\varphi-p_{1}+p_{2}+p_{1} \mu\right)\right) / p_{2} \\
1 \leq \mu \text { のとき、 } & \mu^{\prime}=(1-\varphi) / p_{2}+\mu
\end{array}
$$

図 20 に弱層の有無による塑性率の変化を示す。図中の実線は(7) 式、点線は(8)式による塑性率の予測式である。補強倍率 $p$ が小さい 場合には、減衰項を考慮した(7)式の精度が(8)式よりも良い。なお、 塑性率 $\mu=1$ の近傍では、(6)式の仮定が成り立たないため、実際の 応答解析結果よりも(7)式は過大評価（安全側）になっている。補強 倍率 $p$ が大きくなると、(7),(8)式の差は小さくなり、減衰項を無視 した(8)式でも十分な予測精度となる。

$\mu$ が大きくなるに従い弱層の有無による塑性率の差 $\mu^{\prime}-\mu$ は一 定值に近づく。(8c)式より、 $\mu^{\prime}-\mu$ は弱層倍率 $\varphi$ と骨格曲線の 2 次 勾配 $p_{2}$ から簡単に評価でき、 $p_{2}$ が大きいほど弱層の塑性率増大が 抑制できることがわかる。 

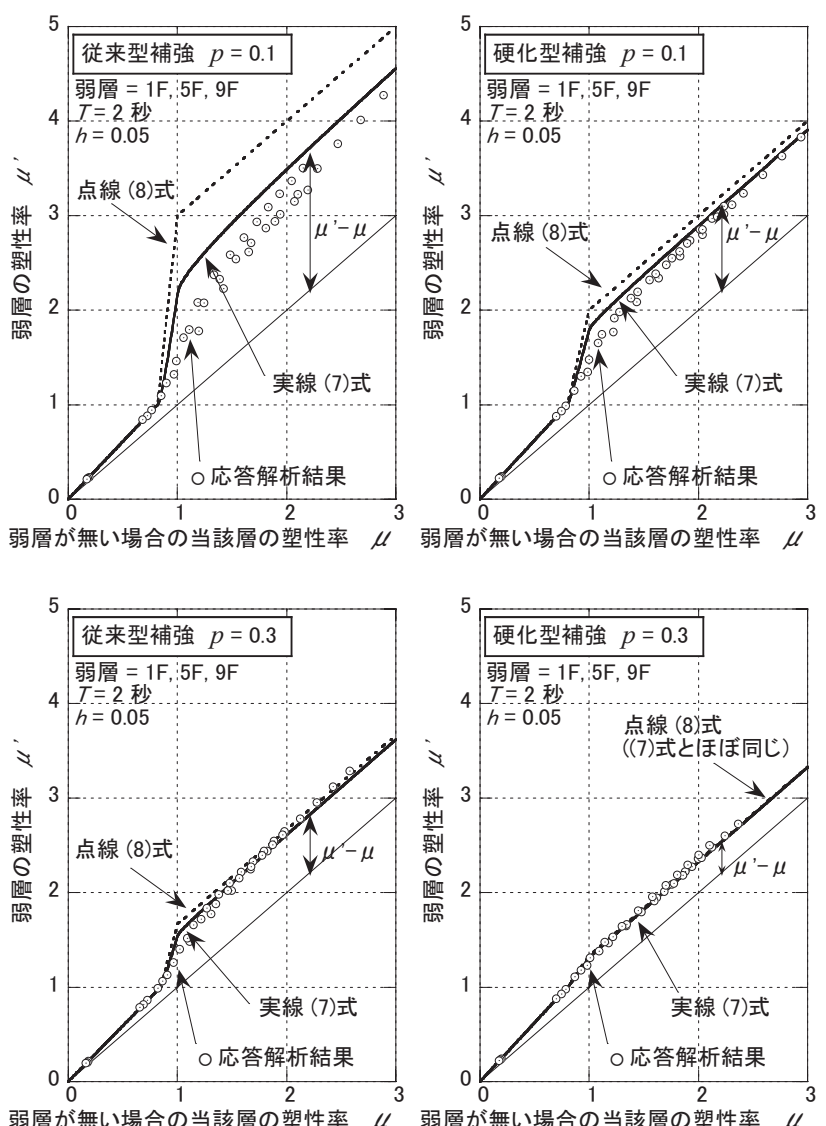

図 20 弱層の有無による塑性率の変化

\section{5. 応答予測}

(2),(3),(4),(7)式を用いると、弱層なしモデルを対象とした少数の 応答解析結果から任意の条件での塑性率や転倒モーメントを予測す ることができる。図 21 に応答予測手順を示す。表 1 の解析条件の 中から、波形倍率 $\gamma=1,3$ の弱層なしの応答解析結果のみを用いて、 弱層ありの全ケースの予測を行った。図 22 に転倒モーメントの予 測結果を、図 23 に塑性率の予測結果を示す。補強倍率 $p$ が小さく (6)式が成り立たないために過大評価（安全側）となるケースも含ま れているが、全体的には良い近似となっている。
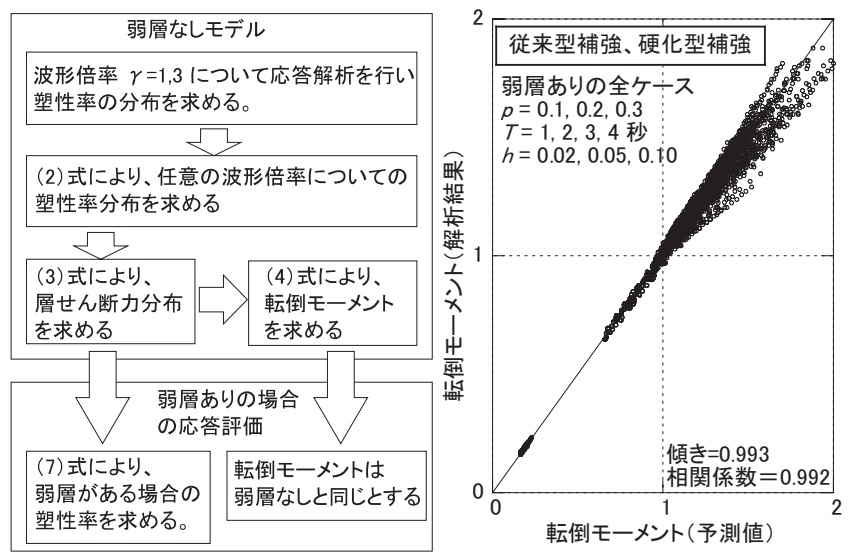

図 21 応答予測手順

図 22 転倒モーメントの予測結果
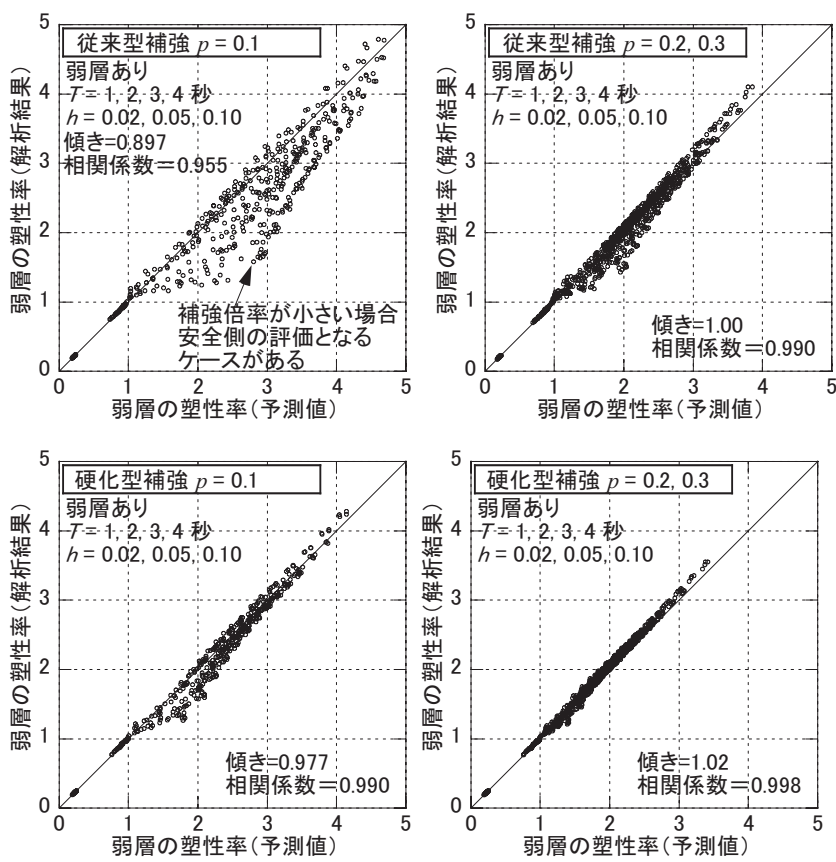

図 23 塑性率の予測結果

6. まとめ

ギャップ率 $g=1$ の場合について、硬化型補強したせん断型多層モ デルの非線形時刻歴解析を行い、以下の知見が得られた。なお、ギ ヤップ率 $g$ が変わる場合の応答低減の定量的評価については今後 の課題とする。

1）転倒モーメントの増大は、補強による初期剛性の増加が小さい ほど抑制できる。

2）弱層がある場合の塑性率の増大は、骨格曲線の 2 次勾配が大き いほじ抑制できる。

3）硬化型補強は、初期剛性を増やさずに 2 次勾配を大きくするこ とができるため、転倒モーメントの増大を抑制でき、弱層が女 る場合にも損傷集中を抑制できる。

4）従来型補強で塑性率 $\mu=1.5 \sim 3.0$ の応答が想定される場合に は、硬化型補強にすることによって、最大塑性率と転倒モーメ ントの両方を低減できる。

5）補強倍率 $p$ が大きい場合には、弱層の有無による層せん断力の 変化は極めて小さい。この知見を用いると、弱層なしモデルの 応答解析結果から弱層がある場合の塑性率や転倒モーメントを 予測可能である。

\section{参考文献}

1）島崎和司： RC 柱造の地震後の残存軸耐力に関する研究, 日本建築学会構 造系論文集 第637 号, pp. 537-542，2009.3

2）那良幸太郎、藤永隆、孫玉平: 載荷履歴を受けた RC 柱の補修後性能に関 する実験的研究, 日本建築学会大会学術講演梗概集, C-2, pp. 563-564, 2010.9

3）佐原守、秋野矩之、五十嵐治世、龟井功、森脇登美雄 : 兵庫県南部地震で 被災した上部構造一杭系の被害分析 一杭基礎が損傷した事例一（その 1 上部構造および杭基礎の被害状況），日本建築学会大会学術講演梗概集， B-1, pp. 515-516, 1998. 9

4）大和真一、村上浩、吉田茂: 杭頭を固定したコンクリート杭の軸力水平載 荷試験による地震時の被害推定, 日本建築学会大会学術講演梗概集, pp. 2429-2430, 1984. 10 
5）渡辺宏一、田村和夫：ギヤップ連層壁架構の地震応答特性, 日本建築学会 大会学術講演梗概集，B-2，pp. 883-884，1998.9

6）渡辺宏一、田村和夫 : ギャップ連層壁架構の基本振動特性, 第 10 回日本 地震工学シンポジウム, pp. 2753-2758, 1998. 11

7) 渡辺宏一、中井正一: 硬化型復元力特性をもつ構造の最大層せん断力, 日 本建築学会大会学術講演梗概集，B-2，pp. 955-956，2012.9

8）小堀鐸二、南井良一郎：地震による構造物の非線型振動について（その 2 構造物力学特性の人為的非線型化過程）, 日本建築學會論文集 第 52 号, pp. $41-48,1956.3$

9）本間誠、堀則男、井上範夫 : エネルギー応答に基づいた地震を受ける鉄筋 コンクリート建物におけるダンパーと変形制御機構の設計, 日本建築学会 構造系論文集 第 618 号, pp. 49-56, 2007.8

10）秋山宏：エネルギーの釣合いに基づく建築物の耐震設計，技報堂出版, pp. 48-55, 1999

11）小堀鐸二、南井良一郎、井上豊、久德敏治、藤井正経 : 高層構造物の適 正動力学特性<特殊なモデルについての考察 >, 日本建築学会近畿支部研 究報告集, pp. 109-112, 1968.5

12）小堀鐸二、南井良一郎、井上豊、久徳敏治、平林近衛：高層構造物の適 正動力学特性 <減衰量による考察 $>$, 日本建築学会近畿支部研究報告集, pp. 113-116, 1968.5

13）小堀鐸二、南井良一郎、井上豊、久德敏治: 高層構造物の適正動力学特 性＜塑性領域における一般的傾向＞, 日本建築学会大会学術講演梗概集, pp. 433-434, 1968. 10

14）日本建築学会：建築物の耐震性能評価方法の現状と課題一限界耐力計 算・エネルギー法・時刻歴応答解析一，丸善，pp. 99-140，2009.2

15）笠井和彦、蒲武川：多層スリップ型架構に粘弾性ダンパーを用いた制震 構造の応答制御設計法, 日本建築学会構造系論文集 第 650 号, pp. 781-790, 2010. 4

16）大木洋司、笠井和彦、下田智博 : 減衰がせん断力係数分布へ及ぼす影響 に関する基礎的研究 その 2 減衰の影響を考慮した修正 $\mathrm{Ai}$ 分布, 日本 建築学会大会学術講演梗概集， B-2, p257-258，2006. 9

17）笠井和彦、川鍋佳史：粘性減衰・履歴減衰を併用する構造における動的 特性と地震最大応答の等価線形予測法, 日本建築学会構造系論文集 第 591 号, pp. 43-51, 2005.5

18）日本建築学会：鉄筋コンクリート造建物の勒性保証型耐震設計指針 （案）・同解説，丸善，pp. 114，1997.7

付録 ギャップ率 $g$ を変動させた場合の応答低減について

ギャップ率 $g$ について実施した予備解析について示す。解析条件は、既存 建物の固有周期 $T=2$ 秒、層数 $N=10$ 、減衰定数 $h=0.02,0.05,0.10$ 、弱層 なし、補強倍率 $p=0.1,0.3$ 、ギャップ率 $g=0.0 \sim 1.5$ (0.1 刻み) である。 図 A1 に示寸ように、骨格曲線は塑性率 $\mu=2$ において層せん断力が同じと なるように設定した。解析結果の一例 $(h=0.05 、 p=0.3)$ を図 $\mathrm{A} 2$ に示 す。転倒モーメントは、骨格曲線の層せん断力の大小関係と同じ傾向を示し、 $\mu<2$ ではギャップ率 $g$ が小さいほど、 $\mu>2$ では $g$ が大きいほど転倒モー メントは大きい。なお、多層モデルの場合には、同時に全層の塑性率が同じ 最大值になるとは限らないため、大小関係の逆転は $\mu=2$ 上りも大きな最大 塑性率で発生している。各波形倍率では、ギャップ率 $g$ の変動に伴い解析結 果もなめらかに変動し、ギャップ率 $g=1.0$ 近傍を頂点として「くの字」に折 れ曲がっていることがわかった。そこで、本論文では、応答低減が最も期待 できるギャップ率 $g=1.0$ について検討した。

なお、図 A 3 に示寸ように、ギャップ率 $g=1.0$ の硬化型補強の骨格曲線は、 2 次勾配が $2 p$ のバイリニアと同じである。しかし、骨格曲線を同じにした 従来型補強では、2 次勾配を大きくするに従い履歷吸収エネルギー (薄塗部 の面積）が小さくなるが、硬化型補強は 2 次勾配が大きくなっても履歴吸収 エネルギーは変化しないという違いがある。この点において、本論文で行っ ている従来型補強と硬化型補強の比較は、単に、初期剛性と 2 次勾配が異な るバイリニア復元力を比較したものではない。

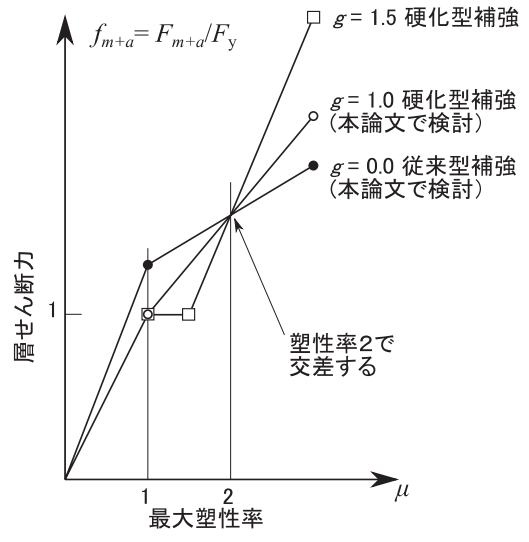

図 A1 骨格曲線 （ギャップ率 $g=0.0,1.0,1.5$ のみを記入 ）

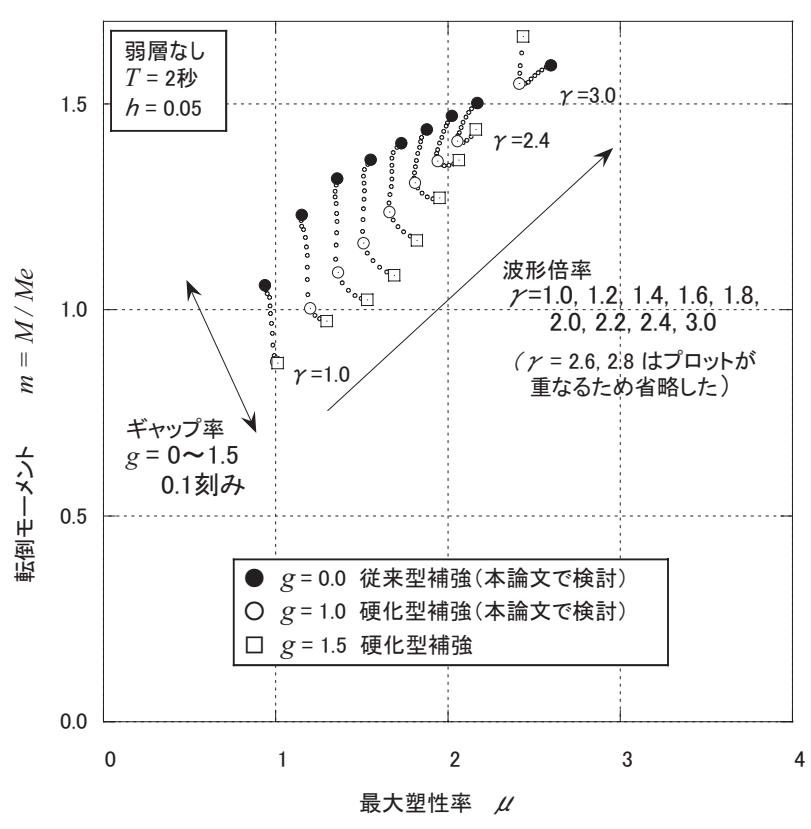

図A2 ギャップ率を変動させた場合の応答低減

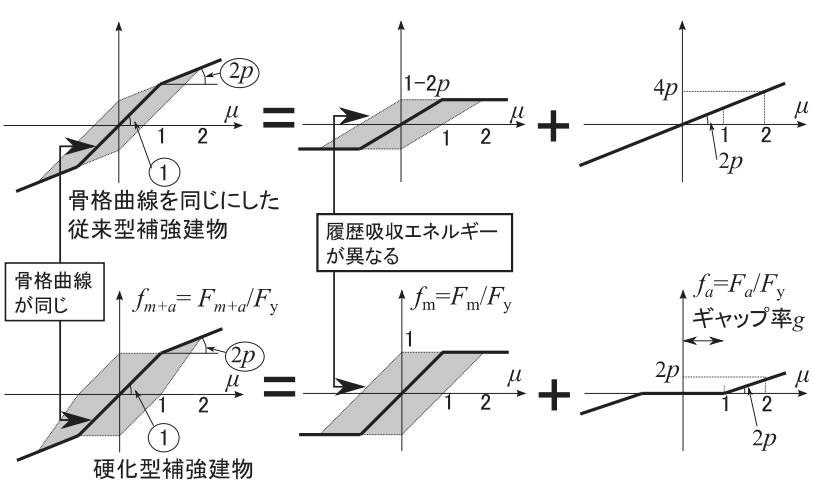

図A3 骨格曲線が同じ従来型補強建物と硬化型補強建物 （2012年11月 8 日原稿受理，2013年 2 月 12 日採用決定） 